УДК 615.273.52/.53:616.831-005.1]-08-084]:001.8

DOI https://doi.org/10.11603/2312-0967.2019.2.10196

\title{
МІСЦЕ АНТИКОАГУЛЯНТІВ У ЛІКУВАННІ ТА ПРОФІЛАКТИЦІ ІШЕМІЧНОГО ІНСУЛЬТУ (ОГЛЯД ДОКАЗОВОЇ БАЗИ ВИКОРИСТАННЯ)
}

\author{
О. Р. Левицька, Б. П. Громовик \\ Львівський національний медичний університет імені Данила Галицького \\ levytska.oksana@gmail.com, hromovyk@gmail.com
}

\section{ІНФОРМАЦІЯ}

Надійшла до редакції / Received 07.05.2019

Після доопрацювання / Revised: 14.05.2019

Прийнято до друку / Accepted: 16.05.2019

\section{Ключові слова}

ішемічний інсульт; антикоагулянти; доказова медицина.

\section{АНОТАЦІЯ}

Мета роботи. Розбір та систематизація даних кокранівських (КО) і систематичних (СО) оглядів та мета-аналізів (MA) щодо застосування антикоагулянтів (АК) при ішемічному інсульті (ii) 3 орієнтацією на нові дані доказової медицини.

Матеріали і методи. Матеріалами для дослідження слугували публікації (KO, CO, MA) в базах даних DORIS та Medline щодо застосування АК при ї, розширений пошук яких здійснено у березні 2019 р. У дослідження включено 6 КО, 8 СО і 4 МА (повнотекстові огляди або абстракти). Використано методи: інорормаційного пошуку, аналізу, синтезу та узагальнення. Систематизація даних здійснювалася за видом антитромботичного засобу, його дозуванням тощо.

Результати й обговорення. Проаналізовано та систематизовано дані щодо есрективності та безпеки використання парентеральних АК (нефракціонованого гепарину (НГ), низькомолекулярних гепаринів (НМГ), гепариноїдів) та пероральних АК (антагоністів вітаміну К, інгібіторів тромбіну чи фактора згортання крові Ха) в гострому періоді іi та його вторинній профрілактиці. При гострому іi АК не мають переваг перед антитромбоцитарними засобами у зниженні смертності та залежності; антикоагулянтна терапія (АКТ) не зменшує смертність від усіх причин; вона дещо зменшує частоту повторних іi, більше зменшує емболію легень і тромбози глибоких вен. В останньому випадку НМг або гепариноїди перевершують НГ. АКТ при гострому іі збільшувала кількість внутрішньочерепних (ВЧК), екстракраніальних чи внутрішньомозкових (ВМК) крововиливів. Вищі дози АК збільшують ризик ВМК чи ВЧК та не поліпшують загальний результат лікування пацієнтів з гострим іі. Не виявлено користі від тривалої АКТ з метою вторинної профрілактики некардіоемболічного іi або транзиторної ішемічної атаки.

Висновки. Розвиток наукових досліджень у питанні АКТ при іi, еволюція поглядів щодо ролі АК у лікуванні та профрілактиці даної патології засвідчують, що вивчення ефективності та безпеки цієї групи лікарських засобів у сучасній інсультології були та залишаються актуальним напрямом. Враховуючи поповнення доказової бази результатами нових клінічних досліджень, які уже знайшли відображення в рекомендаціях американських асоціацій серця та інсульту, доцільно переглянути та доповнити вітчизняні медико-технологічні документи, які регламентують клінічні аспекти надання медичної допомоги при іi.

ISSN 2312-0967. Фармацевтичний часопис. 2019. № 2 
Вступ. Лікування ішемічного інсульту (iі) потребує використання різних груп лікарських засобів (ЛЗ), основними вимогами до яких $€$ їх клінічна ефективність і безпечність. Джерелами такої інфрормації є дані доказової медицини: кокранівські (КО) і систематичні (CO) огляди та мета-аналізи (МА), яким притаманний найвищий рівень доказів ефективності. У низці попередніх публікацій нами систематизовано доказові дані щодо використання при іі тромболітиків $[1,2]$ та антиагрегантів [3]. Ще однією групою ЛЗ, які застосовуються при іi, $€$ антикоагулянти (АК). Вітчизняні медико-технологічні документи, затверджені у 2012 р., описують особливості застосування АК при іi $[4,5]$. Ці лЗ широко вивчали у багатьох дослідженнях, проте рекомендації щодо їх застосування при іі не завжди однозначні. АК у вигляді парентеральних лікарських форм застосовують для профрілактики та лікування гострих тромбоемболічних розладів, тоді як пероральні лЗ - для тривалої антикоагулянтної терапії (АКТ) [6]. Упродовж десятків років єдиними доступними пероральними АК були антагоністи вітаміну К, зокрема, варфарин. 3 того часу доказова медицина збагатилася результатами нових розвідок, наприклад, сьогодні активно досліджуються нові пероральні АК - інгібітори тромбіну та фрактора згортання крові Ха, що й зумовило актуальність наших пошуків.

Мета роботи. Розбір та систематизація даних КО, СО та МА щодо застосування АК при іі з орієнтацією на нові дані доказової медицини.

Матеріали і методи. Матеріалами для дослідження слугували публікації (КО, СО, МА) в базах даних DORIS (Database of Research in Stroke - база даних досліджень щодо інсульту [7] та Medline Національної медичної бібліотеки США (US National Library of Medicine) 3 ïi електронно-пошуковою системою PubMed [8] щодо застосування АК при іi, розширений пошук яких здійснено у березні 2019 р. У дослідження включено 6 КО, 8 СО і 4 МА (повнотекстові огляди або абстракти).

Використано методи: інформаційного пошуку, аналізу, синтезу та узагальнення. Систематизація даних здійснювалася за такими критеріями: вид антитромботичного ЛЗ (АК: нефракціонований гепарин (НГ), низькомолекулярні гепарини (НМГ), гепариноїди, пероральні АК (антагоністи вітаміну К (варфрарин, френілін тощо), інгібітори тромбіну (ксімелагатран, дабігатран) чи фрактора згортання крові Ха (бетриксабан, дарексабан, фондапаринукс, ривароксабан, апіксабан, едоксабан, ідрапаринукс) та антиагреганти (як ЛЗ порівняння), дозування ЛЗ тощо. У рандомізованих клінічних дослідженнях (РКД) ефективність АК оцінювали за такими показниками, як вплив на смертність, частота повторних інсультів, запобігання тромбозам глибоких вен (ТГВ) та симптомних легеневих емболій; а безпечність - за частотою виникнення внутрішньочерепних (ВЧК), екстракраніальних (ЕКК) та внутрішньомозкових (ВМК) крововиливів.
Результати й обговорення. Наслідки систематизації доказових даних щодо застосування АК при гострому іi представлені в таблиці 1. Встановлено, що більшість КО, СО та МА були присвячені аналізу доказових даних щодо ефективності та безпеки використання НГ, НМГ та гепариноїдів при гострому іi. 3'ясовано такі параметри:

1. Вплив на смертність чи інвалідність. Як видно 3 даних таблиці 1, АК не мають жодних переваг перед антитромбоцитарними засобами у зниженні смертності та залежності. АК порівняно з АСК асоціювалися з певним збільшенням числа смертей наприкінці спостереження [13]. Не було жодних доказів того, що АКТ зменшує смертність від усіх причин при гострому іi $[15,21]$.

У пацієнтів з гострим кардіоемболічним інсультом при застосуванні АК порівняно 3 іншими методами лікування спостерігалася незначна різниця в смертності чи інвалідності в кінці спостереження [19].

Порівняно із НГ, не було ніяких доказів впливу НМГ чи гепариноїдів на смертність від усіх причин [18].

Інтрапроцедурне застосування гепарину під час ендоваскулярного лікування пацієнтів 3 гострим іi пов'язане з вищими показниками смертності та нижчими показниками сприятливих результатів через 1-3 місяці [9].

2. Частота повторних інсультів. Висновки низки КО, СО та МА засвідчують, що АКТ пов'язана із зменшенням частоти повторних іi $[15,17,19,21]$.

3. Симптомна легенева емболія. Застосування АК призводило до зменшення частоти виникнення емболії легень [10, 12, 15, 21].

4. ВЧК, ЕКК та ВМК. АКТ у пацієнтів з гострим іi збільшувала кількість ВЧК, ЕКК чи ВМК [11, 12, 13, $15,17,19,20,21]$.

5. Запобігання ТГВ. Лікування НМГ або гепариноїдами пов'язане із значним зменшенням ТГВ [12]. АВтори усіх КО та СО сходяться на думці, що вказані АК перевершують у цьому випадку НГ [10, 14,16, 18].

У пацієнтів 3 імовірним кардіоемболічним інсультом не спостерігали жодних переваг НМГ порівняно 3 АСК. Тому НМГ не повинні застосовуватись замість АСК при лікуванні пацієнтів 3 гострим іi, у т. ч. 3 імовірним кардіоемболічним інсультом [11].

За даними Whiteley W.N., Adams H.P. Jr., Bath P.M.W. та ін. (2013), не встановлено цілеспрямованого підходу до вибору пацієнтів, які отримали б вигоду від ранньої АКТ при гострому іі. Відтак необхідно переглянути рекомендації щодо рутинного або селективного використання гепаринів при інсульті [20]. Рання АКТ не пов'язана з чистою короткостроковою або довготривалою перевагою у людей $з$ гострим іi. Одержані дані не підтримують планомірне використання будь-яких наявних в даний час АК при гостромy ii $[15,21]$.

Далі нами систематизовано дані щодо впливу дозування АК на результати лікування. B CO Gubitz G.J.,

ISSN 2312-0967. Pharmaceutical review. 2019. № 2 
Sandercock P.A.G., Counsell C.E. (2000) (ЛЗ - НГ, НМГ, гепариноїди, інгібітори тромбіну; 4 РКД, $\mathrm{n}=10$ 543) вказується, що порівняно з низькими, вищі дози всіх типів АК значно підвищили ймовірність симптомного ВЧК (ВШ 2,21; 95 \% ДІ: 1,59-3,06), не зменшили ризику повторного інсульту (ВШ 1,21; 95 \% ДІ: 0,96 1,53), а також смертності від усіх причин (ВШ 1,04; 95\% ДІ: 0,95 - 1,14) [22].

В CO та MA Geeganage C.M., Sprigg N., Bath M.W., Bath P.М. (2013) (Л3 - НГ, НМГ, гепариноїди (низькі дози), 15 РКД) констатується, що співвідношення симптомного ВМК до симптомної емболії легеневої артерії було приблизно однаковим у групі, що приймала гепариноїди (ВР 1,27; 95 \% ДІ: 0,31 - 5,17) та НГ (ВР 0,99; 95 \% ДІ: 0,65 - 1,52), але збільшувалося у пацієнтів, яким застосовували НМГ (ВР 2,1; 95 \% ДІ: 1,03 - 4,28). Тобто НМГ збільшували симптомні ВМК більше, ніж вони зменшували симптомні емболії легеневої артерії у пацієнтів з недавнім іі. Тому їх рутинне застосування не рекомендоване [23].

B CO Jani V.B., Saed A., Mohindroo T. та ін. (2014) (ЛЗ - НГ; 33 РКД, n = 957) вказано, що серед пацієнтів, яким проводили ендоваскулярне лікування та вводили інтрапроцедурно гепарин, кількість симптомних ВМК була значно вищою у тих, хто отримував високу дозу гепарину порівняно 3 низькими дозами (55/257 проти 25/228, p = 0,001) [9].

Встановлено, що вищі дози АК порівняно з низькими дозами збільшують ризик ВМК чи ВЧК та не поліпшують загальний результат лікування пацієнтів 3 гострим іi $[9,22]$. Якщо АК все ж застосовуються для лікування гострого іi, доза повинна бути максимально низькою [22].

Далі нами систематизовано дані доказової медицини щодо використання АК 3 метою вторинної профрілактики іi (табл. 2).

\section{Таблиця 1}

Систематизація доказових даних щодо застосування антикоагулянтів при гострому ішемічному інсульті

\begin{tabular}{|c|c|c|}
\hline $\begin{array}{c}\text { Доказове } \\
\text { джерело, } \\
\text { к-сть РКД й } \\
\text { учасників (n) }\end{array}$ & Результати & Автори, рік \\
\hline 1 & 2 & 3 \\
\hline \multicolumn{3}{|c|}{ НГ } \\
\hline $\begin{array}{l}\text { СО, } 33 \text { РКД, } \\
\mathrm{n}=957\end{array}$ & $\begin{array}{l}\text { Інтрапроцедурне введення гепарину при ендоваскулярному лікуванні хворих } \\
\text { на ї. Рівень сприятливих результатів у проміжку часу } 1-3 \text { місяці був значно } \\
\text { вищим у пацієнтів, які не отримували гепарин порівняно з тими, хто його } \\
\text { отримував (305/472 проти 264/485, p = 0,001), при цьому смертність була } \\
\text { значно нижчою у тих, хто не отримував л3 (107/472 проти } 141 / 485, \text { p=0,02). } \\
\text { Кількість симптомних ВМК не відрізнялася в обох групах хворих }(80 / 485 \text { проти } \\
60 / 472, \text { p=0,09) }\end{array}$ & $\begin{array}{l}\text { Jani V. B., Saed } \\
\text { A., Mohindroo T. } \\
\text { et al., } 2014 \text { [9] }\end{array}$ \\
\hline \multicolumn{3}{|c|}{ НГ, НМГ } \\
\hline $\begin{array}{l}\text { СО, } 3 \text { РКД, } \\
n=2028\end{array}$ & $\begin{array}{l}\text { Використання НМГ було пов'язане із значним зменшенням кількості ТГВ (ВШ* } \\
\text { 0,54; 95\% ДІ 0,41 - 0,70, p <0,001) і зменшенням кількості легеневих емболій } \\
\text { (ВШ 0,26; } 95 \text { \% ДІ: 0,07 - 0,95; p = 0,042) за відсутності різниці в кількості ВЧК } \\
\text { або смертності залежно від типу антитромботичного л3 }\end{array}$ & $\begin{array}{l}\text { Shorr A. F., } \\
\text { Jackson W. L., } \\
\text { Sherner J. H., } \\
\text { Moores L. K., } \\
2008 \text { [10] }\end{array}$ \\
\hline \multicolumn{3}{|c|}{ НМГ, АСК } \\
\hline $\begin{array}{l}\text { СО, } 2 \text { РКД, } \\
n=1933\end{array}$ & $\begin{array}{l}\text { На відміну від АСК лікування НМГ значно знизило симптомну венозну } \\
\text { тромбоемболію (ВШ 0,29, } 95 \text { \% ДІ: 0,12-0,66) і збільшило кількість великих } \\
\text { ЕКК (ВШ 2,57; } 95 \text { \% ДІ: 1,01- 6,52) та незначно підвищило смертність (ВШ } \\
\text { 1,35; } 95 \text { \% ДІ: 0,87-2,08) і симптомні ВЧК (ВШ 1,82; } 95 \text { \% ДІ: 0,68 - 4,87), котрі } \\
\text { виникали значно частіше у пацієнтів, яких лікували НМГ упродовж } 24 \text { год після } \\
\text { початку інсульту (Вш 4,26; 95\% ДІ: 1,04-17,4). Повторний інсульт (ВШ 1,24; } \\
95 \text { \% ДІ: 0,79-1,94), погіршення під час лікування (ВШ 1,13; } 95 \% \text { ДІ: 0,85-1,50) } \\
\text { та смертність (ВШ 1,00; } 95 \% \text { ДІ: 0,77-1,30) або залежність (ВШ 1,03; 95\% ДІ: } \\
\text { 0,85-1,25) не відрізнялися у двох групах пацієнтів }\end{array}$ & $\begin{array}{l}\text { Bath P., } \\
\text { Leonardi-Bee J., } \\
\text { Bath F., } 2002[11]\end{array}$ \\
\hline \multicolumn{3}{|c|}{ НМГ, гепариноїди } \\
\hline $\begin{array}{l}\text { СО, } 11 \text { РКД, } \\
\mathrm{n}=3048\end{array}$ & $\begin{array}{l}\text { Застосування НМГ значно зменшило ТГВ (ВШ 0,27, } 95 \text { \% ДІ: 0,08-0,96) і } \\
\text { симптомну легеневу емболію (ВШ 0,34, 95\% ДІ: 0,17-0,69) та збільшило } \\
\text { кількість ЕКК (ВШ 2,17, } 95 \% \text { ДІ: 1,10 - 4,28) } 3 \text { незначним збільшенням } \\
\text { симптомних ВЧК (ВШ 1,77, } 95 \% \text { ДІ: } 095-3,31)\end{array}$ & $\begin{array}{l}\text { Bath P. M., } \\
\text { Iddenden R., } \\
\text { Bath F. J., } 2000 \\
\text { [12] }\end{array}$ \\
\hline
\end{tabular}

ISSN 2312-0967. Фармацевтичний часопис. 2019. № 2 


\begin{tabular}{|c|c|c|}
\hline 1 & 2 & 3 \\
\hline \multicolumn{3}{|c|}{ НГ, НМГ, АCK } \\
\hline $\begin{array}{l}\text { КО, } 4 \text { РКД, } \\
n=16558\end{array}$ & $\begin{array}{l}\text { АК не перевершували АСК у зниженні смертності або залежності (ВШ 1,07, } \\
95 \% \text { ДІ: 0,98 - 1,15), асоціювалися } 3 \text { певним збільшенням числа смертей } \\
\text { наприкінці спостереження (ВШ 1,10, } 95 \% \text { ДІ: 1,01-1,29), значним підвищеним } \\
\text { ризиком симптомних ВЧК (ВШ 2,35, 95\% ДІ: } 1,49-3,46) \text { і незначним - } \\
\text { будь-якого інсульту (ВШ 1,20, } 95 \% \text { ДІ: 0,99-1,46). Ці нейтральні чи несприятливі } \\
\text { ефекти переважали невеликий, але суттєвий вплив на симптомний ТГВ } \\
\text { (ВШ 1,20, } 95 \% \text { ДІ: 0,07-0,58) }\end{array}$ & $\begin{array}{l}\text { Berge E., } \\
\text { Sandercock P. A. } \\
\text { G., } 2002[13]\end{array}$ \\
\hline \multicolumn{3}{|c|}{ НГ, НМГ, гепариноїди } \\
\hline $\begin{array}{l}\text { СО, } 5 \text { РКД, } \\
\mathrm{n}=705\end{array}$ & $\begin{array}{l}\text { НМГ або гепариноїди перевершують НГ щодо зниження частоти виникнення } \\
\text { ТГВ (ВШ 0,52, } 95 \text { \% ДІ: 0,56-0,79), що спостерігався у } 13 \text { \% і } 22 \text { \% пацієнтів, які } \\
\text { приймали НМГ і НГ відповідно }\end{array}$ & $\begin{array}{l}\text { Counsell C., } \\
\text { Sandercock P., } \\
2002[14]\end{array}$ \\
\hline $\begin{array}{l}\text { СО, } 22 \text { РКД, } \\
n=23577\end{array}$ & $\begin{array}{l}\text { АК не зменшували смертність від усіх причин при гострому іi (ВШ 1,05; } 95 \text { \% ДІ: } \\
\text { 0,98-1,12) (9 РКД, 22570 хворих), проте дещо зменшували повторні іі (ВШ 0,76; } \\
95 \text { \% ДІ: 0,65- 0,88) та запобігали легеневим емболіям (ВШ 0,60; } 95 \text { \% ДІ: 0,44 } \\
\text { - 0,81) на фроні збільшення кількості симптомних ВЧК (ВШ 2,52; } 95 \text { \% ДІ: 1,92 - } \\
\text { 3,30) та ЕКК (ВШ 2,99; } 95 \text { \% ДІ: 2,2 -3,99) }\end{array}$ & $\begin{array}{l}\text { Sandercock P., } \\
\text { Gubitz G., } \\
\text { Counsell C., } \\
2004 \text { [15] }\end{array}$ \\
\hline $\begin{array}{l}\text { СО, } 6 \text { РКД, } \\
n=740\end{array}$ & $\begin{array}{l}\text { Лікування НМГ або гепариноїдами після гострого іi суттєво зменшувало } \\
\text { виникнення ТГВ порівняно з НГ (ВШ 0,52; } 95 \text { \% ДІ: 0,56 - 0,79), проте кількість } \\
\text { інших важливих подій (емболія легень, смерть, ЕКК, ВЧК) була занадто малою, } \\
\text { щоб забезпечити надійну оцінку важливіших переваг та ризиків. Даних про } \\
\text { повторний інсульт або фрункціональні результати не було }\end{array}$ & $\begin{array}{l}\text { Hankey G. J., } \\
\text { Sandercock P., } \\
\text { Counsell C., } \\
\text { Stobbs S. L., } \\
2005 \text { [16] }\end{array}$ \\
\hline $\begin{array}{l}\text { СО, } 8 \text { РКД, } \\
n=4492\end{array}$ & $\begin{array}{l}\text { Негайне застосування АК значно збільшувало кількість симптомних і } \\
\text { безсимптомних ВМК (ВШ 1,72; } 95 \text { \% ДІ: 1,17-2,54) і дещо зменшувало кількість } \\
\text { повторних інсультів (ВШ 0,64; } 95 \% \text { ДІ: 0,47-0,88) }\end{array}$ & $\begin{array}{l}\text { Guedes L. C., } \\
\text { Ferro J. M., } \\
\text { Paciaroni M. et } \\
\text { al., } 2008 \text { [17] }\end{array}$ \\
\hline $\begin{array}{l}\text { КО, } 9 \text { РКД, } \\
n=3137\end{array}$ & $\begin{array}{l}\text { Порівняно із НГ не було доказів впливу НМГ чи гепариноїдів на смерть з усіх причин } \\
\text { (ВШ 1,06; } 95 \text { \% ДІ: 0,78-1,47; } 8 \text { РКД, n = 3102, низька якість доказів). Лікування НМГ } \\
\text { або гепариноїдами пов'язане із значним зменшенням ТГВ порівняно із НГ (ВШ 0,55; } \\
95 \text { \% ДІ: 0,44 - 0,70; } 7 \text { РКД, n = 2585, низька якість доказів) }\end{array}$ & $\begin{array}{l}\text { Sandercock P. A. } \\
\text { G., Leong T. S., } \\
2017[18]\end{array}$ \\
\hline \multicolumn{3}{|c|}{ НГ, НМГ, гепариноїди, АСК } \\
\hline $\begin{array}{l}\text { МА, } 7 \text { РКД, } \\
n=4624\end{array}$ & 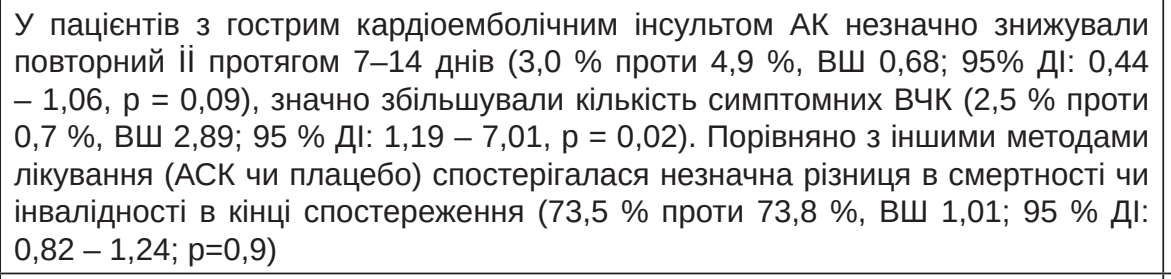 & $\begin{array}{c}\text { Paciaroni M., } \\
\text { Agnelli G., Micheli } \\
\text { S., Caso V., } 2007 \\
\text { [19] }\end{array}$ \\
\hline $\begin{array}{l}\text { СО, } 5 \text { РКД, } \\
n=22655\end{array}$ & $\begin{array}{l}\text { Через } 14 \text { днів } 3 \text { початку лікування у 3,6 \% пацієнтів виникали повторні ї, } \\
\text { майже однакова кількість ЕКК та ВЧК (0,9\% і 0,8 \% відповідно), а близько } \\
\text { двох третин хворих (58,4 \%) померли або були залежними під час кінцевого } \\
\text { спостереження. Пацієнти, яким призначали АК, мали абсолютне підвищення } \\
\text { ризику геморагічних явищ на } 1,6 \% \text { та зниження ризику тромботичних подій } \\
\text { на } 1,4 \% \text { порівняно з тими, яким призначали АСК чи плацебо. Для низьких доз } \\
\text { гепарину проти АСК або плацебо ці цифри становили 0,5\% та 1,4 \% відповідно }\end{array}$ & $\begin{array}{l}\text { Whiteley W. N., } \\
\text { Adams H. P. Jr., } \\
\text { Bath P.M.W. et } \\
\text { al., } 2013 \text { [20] }\end{array}$ \\
\hline \multicolumn{3}{|c|}{ НГ, НМГ, гепариноїди, антагоністи вітаміну К, інгібітори тромбіну } \\
\hline $\begin{array}{l}\text { КО, } 24 \text { РКД, } \\
n=23748\end{array}$ & $\begin{array}{l}\text { Призначення АК упродовж перших } 14 \text { днів після початку інсульту не зменшило } \\
\text { смертність з усіх причин (ВШ 1,05; } 95 \text { \% ДІ: 0,98 - 1,12) (11 РКД, n = 22 776), } \\
\text { але знизило частоту повторних іі (ВШ 0,76; } 95 \text { \% ДІ: 0,65 - 0,88) і симптомів } \\
\text { легеневої емболії (ВШ 0,60; } 95 \text { \% ДІ: 0,44 - 0,81) та збільшило симптомні ВчК } \\
\text { (ВШ 2,55; } 95 \text { \% ДІ: 1,95 - 3,33) та ЕКК (ВШ 2,99; } 95 \text { \% ДІ: 2,24 - 3,99) }\end{array}$ & $\begin{array}{c}\text { Sandercock P. A. } \\
\text { G., Counsell C., } \\
\text { Kane E. J., } 2015 \\
\text { [21] }\end{array}$ \\
\hline
\end{tabular}

ISSN 2312-0967. Pharmaceutical review. 2019. № 2 
Фармакоекономіка

Pharmacoeconomics

Таблиця 2

Систематизація доказових даних щодо застосування антикоагулянтів з метою вторинної профрілактики ішемічного інсульту

\begin{tabular}{|c|c|c|}
\hline Назва Л3 & $\begin{array}{c}\text { Вид доказового джерела, к-сть РКД } \\
\text { та учасників }(\mathrm{n})\end{array}$ & Автори, рік \\
\hline АСК, антагоністи вітаміну К & КО, 8 РКД, $\mathrm{n}=5762$ & $\begin{array}{c}\text { Algra A., De Schryver ELLM, van Gijn } \\
\text { J. et al., 2006 [24] }\end{array}$ \\
\hline
\end{tabular}

Результати. Після ТІА або малого іі ймовірно артеріального походження АКТ (будь-якої інтенсивності) не $\epsilon$ ефективнішою для профрілактики рецидивів іi, ніж антитромбоцитарна терапія (АКТ середньої та високої інтенсивності: ВР* 0,80; 95 \% ДІ: 0,56-1,14 та ВР 1,02; 95\% ДІ: 0,49-2,13 відповідно). Не було жодних доказів того, що АКТ низької інтенсивності підвищує ризик крововиливів порівняно з лікуванням антиагрегантами: ВР 1,27; 95 \% ДІ: 0,79 - 2,03). АКТ середньої та високої інтенсивності антагоністами вітаміну К не була безпечною, оскільки призводила до більш високого ризику виникнення великих крововиливів (АКТ середньої інтенсивності: ВР 1,93; 95 \% ДІ: 1,27 - 2.94; АКТ високої інтенсивності: ВР 9,0; 95 \% ДІ: 3,9 - 21)

*ВР - відносний ризик, тобто зіставлення ризику настання певної події в осіб, які зазнали впливу фрактора ризику відносно контрольної групи

\begin{tabular}{c|c|c}
$\begin{array}{c}\text { НГ, НМГ, } \\
\text { гепариноїди, варфрарин }\end{array}$ & КО, 11 РКД, $n=2487$ & $\begin{array}{c}\text { Sandercock P. A. G., Gibson L. M., } \\
\text { Liu M., 2009 [25] }\end{array}$ \\
\hline
\end{tabular}

Результати. Після першого іi або ТІА не було виявлено впливу АКТ на ризик рецидиву передбачуваного некардіоемболічного іі (ВШ* 0,85; 95 \% ДІ 0,66 до 1,09). Не було також ніяких доказів впливу АКТ на зниження ризику смертності. Смертність від судинних (ВШ 0,86; 95 \% ДІ: 0,66 - 1,13) та будь-яких причин (ВШ 0,95; 95 \% ДІ: 0,73 - 1,24) істотно не відрізнялися між лікуванням та контролем. Проте АК збільшували кількість смертельних ВЧК (ВШ 2,54; 95 \% ДІ 1,19 - 5,45) та великих ЕКК (ВШ 3,43; 95 \% ДІ: 1,94 - 6,08).

*ВШ - відношення шансів, тобто зіставлення для двох ЛЗ відношення ймовірності, що подія відбудеться, до ймовірності, що подія не відбудеться

Для вторинної профрілактики повторних іі після TIA або малого інсульту ймовірно артеріального походження є достатні докази того, що антагоністи вітаміну К у будь-якій дозі не є еорективнішими, ніж антитромбоцитарна терапія, і що АКТ середньої та високої інтенсивності призводить до значного збільшення ускладнень у вигляді великих крововиливів [24].

Порівняно $з$ контролем, не було ніяких даних про користь від тривалої АКТ з метою запобігання рецидиву передбачуваного некардіоемболічного іi або транзиторної ішемічної атаки (TIA), проте існував значний ризик розвитку крововиливів [25].

Як констатується у вітчизняних медико-технологічних документах 2012 р., лікування прямими АК при гострому іі (НГ, НМГ або гепариноїди) не зменшує ризик ані повторних інсультів, ані його прогресування, а також пов'язане зі значним підвищенням частоти геморагічних ускладнень (розвиток ВЧК, ЕКК та ВМК). Не поліпшує результатів інсульту також лікування АК у великих дозах. Проте використання АК у профрілактичних дозах після іi у хворих, які не ходять, дозволяє знизити ризик ТГВ та симптомних легеневих емболій. Якщо немає спеціальних показань (наприклад, тромбоемболія легеневої артерії), при іі не рекомендується використання лікувальних доз АК. 3 огляду на сказане вище при гострому іi застосування АК не повинно бути рутинним $[4,5]$. Разом $з$ тим, нові дані доказової медицини (2013-2017рр.) лягли в основу нових рекомендацій американських асоціацій серця та інсульту (American Heart Association/American Stroke Association, AHA/ASA, 2018). У них йдеться зокрема, про те, що при гострому іі екстрене лікування АК з ме- тою запобігання ранньому рецидиву інсульту, припинення погіршення неврологічних симптомів або покращення результатів після лікування не рекомендується [26]. На даний час користь аргатробану, дабігатрану або іншого інгібітора тромбіну для лікування пацієнтів з іі встановлена недостатньо, тому необхідні подальші клінічні випробування. Користь та безпека інгібіторів фрактора згортання крові Ха при іі також не визначені, що потребує подальших досліджень.

У рекомендаціях AHA/ASA (2018р.) також вказується, що перевага профрілактичного підшкірного введення НГ або НМГ з метою профрілактики ТГВ у знерухомлених пацієнтів з гострим іі недостатньо встановлена, як і не встановлені переваги одного над другим НГ чи НМГ під час проведення АКТ.

Зважаючи на викладене вище, вітчизняні медикотехнологічні документи потребують оновлення рекомендацій.

Висновок. Розвиток наукових досліджень у питанні АКТ при іi, еволюція поглядів щодо ролі АК у лікуванні та профілактиці даної патології засвідчують, що вивчення ефективності та безпеки цієї групи Лз у сучасній інсультології були та залишаються актуальним напрямом. Враховуючи поповнення доказової бази результатами нових клінічних досліджень, які уже знайшли відображення в рекомендаціях американських асоціацій серця та інсульту, доцільно переглянути та доповнити вітчизняні медико-технологічні документи, які регламентують клінічні аспекти надання медичної допомоги при іi.

Конфлікт інтересів: відсутній.

Conflict of interest: authors have no conflict of interest to declare.

ISSN 2312-0967. Фармацевтичний часопис. 2019. № 2 


\title{
МЕСТО АНТИКОАГУЛЯНТОВ В ЛЕЧЕНИИ И ПРОФИЛАКТИКЕ ИШЕМИЧЕСКОГО ИНСУЛЬТА (ОБЗОР ДОКАЗАТЕЛЬНОЙ БАЗЫ ИСПОЛЬЗОВАНИЯ)
}

\author{
О. Р. Левицкая, Б. П. Громовик \\ Львовский национальный медицинский университет имени Данила Галицкого \\ levytska.oksana@gmail.com, hromovyk@gmail.com
}

\begin{abstract}
Цель работы. Разбор и систематизация данных кокрановских (КО) и систематических (СО) обзоров и метаанализов (МА) по применению антикоагулянтов (АК) при ишемическом инсульте (ИИ) с ориентацией на новые данные доказательной медицины.

Материалы и методы. Материалами для исследования послужили публикации (KO, CO, MA) в базах данных DORIS и Medline по применению АК при ИИ, расширенный поиск которых осуществлялся в марте 2019 г. В исследование включено 6 KО, 8 СО и 4 МА (полнотекстовые обзоры или абстракты). Использованы методы: инорормационного поиска, анализа, синтеза и обобщения. Систематизация данных осуществлялась по виду антитромботического средства, его дозирования и т. п.

Результаты и обсуждение. Проанализированы и систематизированы данные по эфффективности и безопасности использования парентеральных АК (несракционированного гепарина (НГ), низкомолекулярных гепаринов (НМГ), гепариноидов) и пероральных АК (антагонистов витамина К, ингибиторов тромбина или фрактора свертывания крови Ха) в остром периоде ИИ и его вторичной профилактике. При остром ИИ АК не имеют преимуществ перед антитромбоцитарными средствами в снижении смертности и зависимости; антикоагулянтная терапия (АКТ) не уменьшает смертность от всехпричин; она несколько уменьшает частоту повторных ИИ, больше уменьшает эмболию легких и тромбозы глубоких вен. В последнем случае НМГ или гепариноиды превосходят НГ. АКТ при остром ИИ увеличивала количество внутричерепных (ВЧК), экстракраниальных или внутримозговых (ВМК) кровоизлияний. Высшие дозы АК увеличивают риск ВМК или ВчК и не улучшают общий результат лечения пациентов с острым ИИ. Не выявлено пользы от длительной АКТ с целью вторичной профилактики некардиоэмболического ИИ или транзиторной ишемической атаки.

Выводы. Развитие научных исследований в вопросе АКТ при ИИ, эволюция взглядов о роли АК в лечении и профрилактике данной патологии свидетельствуют, что изучение эффективности и безопасности этих препаратов в современной инсультологии были и остаются актуальным направлением. Учитывая пополнения доказательной базы результатами новых клинических исследований, которые уже нашли отражение в рекомендациях американских ассоциаций сердца и инсульта, целесообразно пересмотреть и дополнить отечественные медико-технологические документы, регламентирующие клинические аспекты оказания медицинской помощи при иИ.
\end{abstract}

Ключевые слова: ишемический инсульт; антикоагулянты; доказательная медицина.

\section{PLACE OF ANTICOAGULANTS IN TREATMENT AND PREVENTION OF ISCHEMIC STROKE (REVIEW OF EVIDENCE BASE OF USE)}

\author{
O. R. Levytska, B. P. Hromovyk \\ Danylo Halytsky Lviv National Medical University \\ levytska.oksana@gmail.com, hromovyk@gmail.com
}

The aim of the work. Dissemination and systematization of Cochrane and systematic reviews as well as meta-analyses in terms of the use of anticoagulants for ischemic stroke with a focus on new evidence-based medicine.

Materials and Methods. The materials for the study included publications (Cochrane and systematic reviews and metaanalyses) in DORIS and Medline databases on the use of anticoagulants for ischemic stroke. The extended search of the aforementioned databases was performed in March 2019. The study includes 6 Cochrane reviews, 8 systematic reviews and 4 meta-analyses (full text reviews or abstracts). Methods used: information search, analysis, synthesis and generalization. The systematization of data was performed according to the type of antithrombotic agent, its dosage, etc. Results and Discussion. Data on efficacy and safety of the use of parenteral anticoagulants (unfractionated heparin (UFH), low molecular weight heparin (LMWH), heparinoids) and oral anticoagulants (vitamin K antagonists, thrombin inhibitors or blood coagulation factor $\mathrm{Xa}$ ) in the acute period of ischemic stroke and its secondary prevention have been analyzed and systematized. In acute ischemic stroke, anticoagulants do not have any benefits over antiplatelet therapy in reducing mortality and dependence; anticoagulant therapy does not reduce mortality from all causes; it slightly reduces the frequency of repeated ischemic strokes, as well as further decreases pulmonary embolism and deep vein thrombosis. In the latter case, LMWH or heparinoids exceed UFH. Anticoagulant therapy in acute ischemic stroke increased the number of intracranial $(\mathrm{IHC})$, extracranial or intracerebral $(\mathrm{ICH})$ hemorrhages. Higher doses of anticoagulants increase the risk of

ISSN 2312-0967. Pharmaceutical review. 2019. № 2 
$\mathrm{ICH}$ or IHC and do not improve the overall outcome of treatment for patients with acute ischemic stroke. No benefit from long-acting anticoagulant therapy for the secondary prevention of non-cardioembolic ischemic stroke or transient ischemic attack was found.

Conclusions. The development of research in the field of anticoagulant therapy in ischemic stroke, the evolution of views on the role of anticoagulants in the treatment and prevention of this pathology indicate that the study of the efficacy and safety of this group of drugs in modern stroke research has been and remains an important trend. Given the replenishment of the evidence base with the results of new clinical studies that have already been reflected in the recommendations of the American Heart Association and the American Stroke Association, it is advisable to revise and supplement the domestic medical and technological documents that regulate clinical aspects of the provision of medical care in ischemic stroke.

Key words: ischemic stroke; anticoagulants; evidence-based medicine.

\section{Список літератури}

1. Левицька О. Р. Перспективи використання тенектеплази при ішемічному інсульті з погляду доказовості / О. Р. Левицька, Б. П. Громовик, Г. М. Пришляк // Актуальні питання фрармацевтичної і медичної науки та практики. - 2018. - Т. 11, № 2(27). - С. 245-250.

2. Левицкая О. Р. Тромболитическая терапия при ишемическом инсульте: доказательная база использования / О. Р. Левицкая, Б. П. Громовик // Наука и инновация. - 2018. - № 2. - С. 188-194.

3. Левицька О. Р. Антитромбоцитарна терапія ішемічного інсульту з позицій доказової медицини / О. Р. Левицька // Фармацевтичний часопис. - 2018. - № 4(48). - С.69-76.

4. Сучасні принципи діагностики та лікування хворих із гострим ішемічним інсультом та TIA. Адаптована клінічна настанова, заснована на доказах : наказ МОЗ України від 03.08.2012 р. № 602 «Про затвердження та впровадження медико-технологічних документів, розроблених на засадах доказової медицини» (інсульт) [Електронний ресурс]. - 2012. - Режим доступу : http://www.moz.gov.ua/ua/portal/dn_20120127_p. html.

5. Рекомендації щодо ведення хворих з ішемічним інсультом та транзиторною ішемічною атакою. Адаптована клінічна настанова, заснована на доказах : наказ МОЗ України від 03.08.2012 р. № 602 «Про затвердження та впровадження медико-технологічних документів зі стандартизації медичної допомоги при ішемічному інсульті» [Електронний ресурс]. - 2012. - Режим доступу : http://www.moz.gov.ua/ua/portal/ dn_20120803_602.html

6. Karthikeyan G. New oral anticoagulants: not quite there yet / G. Karthikeyan, J. W. Eikelboom, J. Hirsh // Polskie Archiwum Medycyny Wewnetrznej. - 2009. - Vol. 119 (1-2). - P. 53-57.

7. DORIS. Database of Research in Stroke [Electronic resource]. - Access mode : http://www.askdoris.org/

8. PubMed: [сайт]. - Електронний ресурс. - Режим доступу: https://www.ncbi.nlm.nih.gov/pubmed/

9. Intra-procedural heparin increases mortality and reduces rates of favorable outcome in acute ischemic stroke patients undergoing endovascular treatment. [Abstract] [Electronic resource] / V. B. Jani, A. Saed, T. Mohindroo [et al.] // Neurology. - 2014. - Vol. 82, No. 10 Supplement P4.218. - Access mode : http://www.neurology. org/content/82/10_Supplement/P4.218
10. Differences between low-molecular-weight and unfractionated heparin for venous thromboembolism prevention following ischemic stroke. A metaanalysis [Electronic resource] / A. F. Shorr, W. L. Jackson, J. H. Sherner, L. K. Moores // Chest. - 2008. - Vol. 133. - P. 149-155. - Access mode : https://www.ncbi.nlm. nih.gov/pubmed/17925410

11. Bath P. Low molecular weight heparin versus aspirin for acute ischemic stroke: a systematic review [Electronic resource] / P. Bath, J. Leonardi-Bee, F. Bath // Journal of Stroke and Cerebrovascular Diseases. 2002. - Vol. 11(2). - P. 55-62. - Access mode: http:// www.strokejournal.org/article/S1052-3057(02)000149/fulltext

12. Bath P. M. Low molecular weight heparins and heparinoids in acute ischemic stroke: a systematic review [Abstract] [Electronic resource] / P. M. Bath, R. Iddenden, F. J. Bath / Stroke. - 2000. - Vol. 31(1). - P. 311 (Abst.P73). - Access mode : https://www.ncbi.nlm.nih. gov/pubmed/10884486

13. Berge E. Anticoagulants versus antiplatelet agents for acute ischemic stroke [Electronic resources] / E. Berge, P. A. G. Sandercock // Cochrane Database of Systematic Reviews. - 2002. - Issue 4. Art. No.: CD003242. DOI:10.1002/14651858.CD003242. - ACcess mode : https://www.cochranelibrary.com/cdsr/ doi/10.1002/14651858.CD003242/abstract

14. Counsell C. Low-molecular-weight heparins or heparinoids versus standard unfractionated heparin for acute ischemic stroke (Cochrane review) [Electronic resource] / C. Counsell, P. Sandercock // Stroke. - 2002. - Vol. 33. - P. 1925-1926. - Access mode : http:// stroke.ahajournals.org/content/33/7/1925

15. Sandercock P. Anticoagulants for acute ischemic stroke [Electronic resource] / P. Sandercock, G. Gubitz, C. Counsell // Stroke. - 2004. - Vol. 35. - P. 29162917. - Access mode : http://stroke.ahajournals.org/ content/35/12/2916

16. Low-molecular-weight heparins or heparinoids versus standard unfractionated heparin for acute ischemic stroke [Electronic resources] / G. J. Hankey, P. Sandercock, C. Counsell, S. L. Stobbs // Stroke. - 2005. Vol. 36. - P. 2045-2046. - Access mode : http://stroke. ahajournals.org/content/36/9/2045

17. A systematic review of immediate anticoagulation for ischemic stroke of presumed cardioembolic origin [Let-

ISSN 2312-0967. Фармацевтичний часопис. 2019. № 2 
ter] [Electronic resource] / L. C. Guedes, J. M. Ferro, M. Paciaroni [et al.] // Stroke. - 2008. - Vol. 39. P. e81-83. - Access mode : https://www.ahajournals. org/doi/pdf/10.1161/STROKEAHA.107.513200

18. Sandercock P. A. G. Low-molecular-weight heparins or heparinoids versus standard unfractionated heparin for acute ischemic stroke [Electronic resource] / P. A. G. Sandercock, T. S. Leong // Cochrane Database of Systematic Reviews. - 2017. - Issue 4. Art. No.: CD000119. DOI: 10.1002/14651858.CD000119. pub4. - Access mode : http://cochranelibrary-wiley. com/doi/10.1002/14651858.CD000119.pub4/full

19. Efficacy and safety of anticoagulant treatment in acute cardioembolic stroke. A meta-analysis of randomized controlled trials [Electronic resource] / M. Paciaroni, G. Agnelli, S. Micheli, V. Caso // Stroke. - 2007. Vol. 38. - 423-430. - Access mode : https://www.ncbi. nlm.nih.gov/pubmed/17204681

20. Targeted use of heparin, heparinoids, or low-molecular-weight heparin to improve outcome after acute ischemic stroke: an individual patient data meta-analysis of randomised controlled trials [Electronic resource] $/$ W. N. Whiteley, H. P. Jr. Adams, P. M. W. Bath [et al.] // Lancet Neurology. - 2013. - Vol. 12. - P. 539-545. - Access mode : https://www.thelancet.com/journals/ laneur/issue/vol12no6/PIIS1474-4422(13)X7031-0

21. Sandercock P. A. G. Anticoagulants for acute ischemic stroke [Electronic resources] / P. A. G. Sandercock, C. Counsell, E. J. Kane // Cochrane Database of Systematic Reviews. - 2015. - Issue 3. Art. No.: CD000024. DOI: 10.1002/14651858.CD000024. pub4. - Access mode : http://cochranelibrary-wiley. com/doi/10.1002/14651858.CD000024.pub4/full

22. Gubitz G. J. Immediate anticoagulant therapy for acute ischemic stroke: a systematic review of seven randomized controlled trials directly comparing different doses of the same anticoagulant [Abstract of the 25th International Stroke Conference] [Electronic resources] /

\section{References}

1. Levytska OR, Hromovyk BP, Pryshliak HM. [Prospects of tenecteplase use for ischemic stroke in evidence-based approach]. Aktualni pytannia farmatsevtychnoi i medychnoi nauky ta praktyky. 2018;2(27): 245-50. Ukrainian.

2. Levytskaya OR, Gromovyk BP. [Thrombolytic therapy in ischemic stroke: evidence-based use]. Nauka i innovatsiya. 2018;2: 188-94. Russian.

3. Levytska OR. [Antiplatelet therapy of ischemic stroke from the positions of evidence-based medicine]. Farmatsevtychnyi chasopys. 2018;4(48): 69-76. Ukrainian.

4. Order of the Ministry of Health of Ukraine "On approval and introduction of medical-and-technological documents for standardization of care in ischemic stroke. Modern principles of diagnosis and treatment of patients with acute ischemic stroke and TIA. Adapted clinical guideline based on evidence" of August 03, 2012, No. 602. [Electronic resource]. Available from: http:// www.moz.gov.ua/ua/portal/dn_20120803_602.html [Accessed March 2019]. Ukrainian.
G. J. Gubitz, P. A. G. Sandercock, C. E. Counsell // Stroke. - 2000. - Vol. 31(1). - P. 308 (Abst.P61). Access mode : https://www.ahajournals.org/doi/ pdf/10.1161/01.STR.31.1.275

23. Balance of symptomatic pulmonary embolism and symptomatic intracerebral hemorrhage with low-dose anticoagulation in recent ischemic stroke: a systematic review and meta-analysis of randomized controlled trials [Electronic resource] / C. M. Geeganage, N. Sprigg, M. W. Bath, P. M. Bath // Journal of Stroke and Cerebrovascular Diseases. - 2013. - Vol. 22 (7). - P. 10181027. - Access mode : https://www.ncbi.nlm.nih.gov/ pubmed/22516428

24. Oral anticoagulants versus antiplatelet therapy for preventing further vascular events after transient ischemic attack or minor stroke of presumed arterial origin [Electronic resource] / A. Algra, E. L. L. M. De Schryver, J. van Gijn [et al.] // Cochrane Database of Systematic Reviews. - 2006. - Issue 3. Art. No.: CD001342. DOI: 10.1002/14651858.CD001342.pub2. https:// www.cochranelibrary.com/cdsr/doi/10.1002/14651858. CD001342.pub2/epdf/abstract

25. Sandercock P. A. G. Anticoagulants for preventing recurrence following presumed non-cardioembolic ischemic stroke or transient ischemic attack [Electronic resources] / P. A. G. Sandercock, L. M. Gibson, M. Liu // Cochrane Database of Systematic Reviews. - 2009. Issue 2. Art. No.: CD000248. DOI: 10.1002/14651858. CD000248.pub2. - Access mode: http://cochranelibrary-wiley.com/doi/10.1002/14651858.CD000248. pub2/full

26. AHA/ASA Guideline. 2018 Guidelines for the Early Management of Patients With Acute Ischemic Stroke: A Guideline for Healthcare Professionals From the American Heart Association/American Stroke Association [Electronic resources]. - Available from : http:// stroke.ahajournals.org/content/early/2018/01/23/ STR.0000000000000158

5. Order of the Ministry of Health of Ukraine "On approval and introduction of medical-and-technological documents for standardization of care in ischemic stroke. Recommendations for the management of patients with ischemic stroke and transient ischemic attack. Adapted clinical guideline based on evidence" of August 03, 2012, No. 602. Available from: http://www.moz.gov.ua/ ua/portal/dn_20120803_602.html [Accessed March 2019]. Ukrainian.

6. Karthikeyan G, Eikelboom JW, Hirsh J. New oral anticoagulants: not quite there yet. Polskie Archiwum Medycyny Wewnetrznej. 2009;119(1-2): 53-7.

7. DORIS. Database of Research in Stroke [Electronic resources]. Available from: http://www.askdoris.org/ [Accessed March 2019].

8. PubMed: [Electronic resources]. Available from: https:// www.ncbi.nlm.nih.gov/pubmed/ [Accessed March 2019].

9. Jani VB, Saed A, Mohindroo T, Qureshi M, Hussain S,

ISSN 2312-0967. Pharmaceutical review. 2019. № 2 
Suri F et al. Intra-procedural heparin increases mortality and reduces rates of favorable outcome in acute ischemic stroke patients undergoing endovascular treatment. Neurology. 2014;82(10 Supplement): 4.218.

10. Shorr AF, Jackson WL, Sherner JH, Moores LK. Differences between low-molecular-weight and unfractionated heparin for venous thromboembolism prevention following ischemic stroke. A metaanalysis. Chest. 2008;133(1): 149-55.

11. Bath P, Leonardi-Bee J, Bath F. Low molecular weight heparin versus aspirin for acute ischemic stroke: a systematic review. J Stroke Cerebrovasc Dis. 2002;11(2): 55-62.

12. Bath PM, Iddenden R, Bath FJ. Low molecular weight heparins and heparinoids in acute ischemic stroke: a systematic review. Stroke. 2000;31(1): 311 (Abst.P73).

13. Berge E, Sandercock PAG. Anticoagulants versus antiplatelet agents for acute ischemic stroke. Cochrane Database of Systematic Reviews. 2002;4. Art. No.: CD003242. DOI:10.1002/14651858.CD003242.

14. Counsell C, Sandercock P. Low-molecular-weight heparins or heparinoids versus standard unfractionated heparin for acute ischemic stroke (Cochrane review). Stroke. 2002;33: 1925-26

15. Sandercock P, Gubitz G, Counsell C. Anticoagulants for acute ischemic stroke. Stroke. 2004;35: 2916-17.

16. Hankey GJ, Sandercock P, Counsell C, Stobbs SL. Low-molecular-weight heparins or heparinoids versus standard unfractionated heparin for acute ischemic stroke. Stroke. 2005;36: 2045-46.

17. Guedes LC, Ferro JM. A systematic review of immediate anticoagulation for ischemic stroke of presumed cardioembolic origin. Stroke. 2008;39: e81-2.

18. Sandercock PAG, Leong TS. Low-molecular-weight heparins or heparinoids versus standard unfractionated heparin for acute ischemic stroke. Cochrane Database of Systematic Reviews. 2017;4. Art. No.: CD000119. DOI: 10.1002/14651858.CD000119.pub4.

19. Paciaroni M, Agnelli G, Micheli S, Caso V. Efficacy and safety of anticoagulant treatment in acute cardioem- bolic stroke. A meta-analysis of randomized controlled trials. Stroke. 2007;38: 423-30.

20. Whiteley WN, Adams HPJr, Bath PMW, Berge E, Sandset PM, Dennis M et al. Targeted use of heparin, heparinoids, or low-molecular-weight heparin to improve outcome after acute ischemic stroke: an individual patient data meta-analysis of randomised controlled trials. Lancet Neurology. 2013;12: 539-45.

21. Sandercock PAG, Counsell C, Kane EJ. Anticoagulants for acute ischemic stroke. Cochrane Database of Systematic Reviews. 2015;3. Art. No.: CD000024. DOI: 10.1002/14651858.CD000024.pub4.

22. Gubitz GJ, Sandercock PAG, Counsell CE. Immediate anticoagulant therapy for acute ischemic stroke: a systematic review of seven randomized controlled trials directly comparing different doses of the same anticoagulant. Stroke. 2000;31(1): 308 (Abst.P61).

23. Geeganage CM, Sprigg N, Bath MW, Bath PM. Balance of symptomatic pulmonary embolism and symptomatic intracerebral hemorrhage with low-dose anticoagulation in recent ischemic stroke: a systematic review and meta-analysis of randomized controlled trials. J Stroke Cerebrovasc Dis. 2013;22(7): 1018-27.

24. Algra A, De Schryver ELLM, van Gijn J, Kappelle LJ, Koudstaal PJ. Oral anticoagulants versus antiplatelet therapy for preventing further vascular events after transient ischemic attack or minor stroke of presumed arterial origin. Cochrane Database of Systematic Reviews 2006, Issue 3. Art. No.: CD001342. DOI: 10.1002/14651858.CD001342.pub2.

25. Sandercock PAG, Gibson LM, Liu M. Anticoagulants for preventing recurrence following presumed noncardioembolic ischemic stroke or transient ischemic attack. Cochrane Database of Systematic Reviews. 2009;2. Art. No.: CD000248. DOI: 10.1002/14651858. CD000248.pub2.

26. AHA/ASA Guideline. 2018 Guidelines for the Early Management of Patients With Acute Ischemic Stroke: A Guideline for Healthcare Professionals From the American Heart Association/American Stroke Association.

\section{Відомості про авторів:}

Левицька О. Р. - канд. фрармац. н., доцент кафедри організації та економіки фрармації, Львівський національний медичний університет імені Данила Галицького, Львів, Україна. E-mail: levytska.oksana@gmail.com, ORCID 00000002-8113-2587

Громовик Б. П. - д. фрармац. Н., профресор, завідувач кафедри організації та економіки фрармації, Львівський національний медичний університет імені Данила Галицького, Львів, Україна. E-mail: hromovyk@gmail.com, ORCID 0000-0002-6459-6021

\section{Information about the authors:}

Levytska O. R. - PhD (Pharmacy), Associate Professor of the Department of Organization and Economics of Pharmacy, Danylo Halytsky Lviv National Medical University, Lviv, Ukraine. E-mail: levytska.oksana@gmail.com, ORCID 0000-00028113-2587

Hromovyk B. P. - DS (Pharmacy), Professor, Head of the Department of Organization and Economics of Pharmacy, Danylo Halytsky Lviv National Medical University, Lviv, Ukraine. E-mail: hromovyk@gmail.com, ORCID 0000-0002-6459-6021

ISSN 2312-0967. Фармацевтичний часопис. 2019. № 2 